\title{
Theoretical-methodological Approach of Research on the Production of New Mathematical Knowledge by Education Experts
}

\author{
Rosilda dos Santos Morais ${ }^{1 *}$
}

${ }^{1}$ Universidade Federal de São Paulo (UNIFESP), BRAZIL
${ }^{\star}$ Corresponding Author: rosildamorais7@gmail.com

Citation: Morais, R. d. S. (2020). Theoretical-methodological Approach of Research on the Production of New Mathematical Knowledge by Education Experts. Pedagogical Research, 5(3), em0069. https://doi.org/10.29333/pr/8272

\begin{abstract}
ARTICLE INFO
Received: 28 Feb. 2020

Accepted: 11 May 2020

ABSTRACT

This paper aims at making theoretical-methodological contributions to investigations that analyze the production and systematization of knowledge about teacher training and teaching by experts in education. To do so, we consider studies in the fields of History of Education and History of Mathematics Education. Our research work is justified, in the historiographical field, through the nature of the knowledge we intend to analyze, that is, the knowledge systematized by experts in regulations, decrees, teaching manuals, textbooks, school notebooks, etc. The study of such knowledge is interested in 1) enabling the understanding of the processes and dynamics of the constitution of knowledge in training and in teaching from a historical perspective; and in 2) highlight on the education expert 's role in the production process of such knowledge, which are considered here as "mathematics to teach" and "mathematics for teaching", which are, respectively, a teacher's object of work and working tools. Our investigation supports the hypothesis that "the different types of mathematics" change over time, and that education experts are the bringers of such change.
\end{abstract}

Keywords: experts, knowledge to teach, knowledge for teaching, teaching professional knowledge, history of mathematics education

\section{INTRODUCTION}

There seems to be a consensus that the knowledge harnessed in training and in teaching changes over time ${ }^{1}$. Based on such premise, a branch of historiographical research analyzes the processes and dynamics that involve such changes, considering the hypothesis that experts are production bringers of new knowledge. Because it is located in the field of education sciences, the reference - necessary given the polysemy of the concept "expert" - is the "expert in education".

The concept of expert, in a broad conception, is not new. Shanteau (1992), in the article "Competence in Experts: The Role of Task Characteristics", pointed its uses already in the $19^{\text {th }}$ century $\mathrm{BC}^{2}$, whereas its research "appears" in the $19^{\text {th }}$ century CE. The latter interests our study - the research on experts, more specifically on the institutionalization process of the expert in education, which happened, according to Hofstetter et al. $(2013)^{3}$, when the State emerged as the institution responsible for public instruction, and when the disciplinary field "education sciences" ${ }^{4}$ arose. Such phenomenon is justified by governor's impossibility of assessing real in itself. Therefore, "expertise" "started to integrate the process of presentation and elaboration of public actions. In addition, it seems to have become a mandatory passageway that cannot be ignored by political players in the management of public issues (Dumoulin et al., 2005).

\footnotetext{
${ }^{1}$ Hofstetter and Schneuwly (2009a); Ziegles and Loo (2015); Valente et al. (2017).

${ }^{2}$ Such possible "origins" of the term "expert" are conflicting. Burke (2017), for instance, states that it dates back to the first decades of the $19^{\text {th }}$ century CE (Common Era) in Great Britain.

${ }^{3}$ This article was published in Brazil, in Portuguese, under the title "Penetrar na verdade da escola para se ter elementos concretos de sua avaliação"- A irresistivel institucionalização do expert em educação (século XIX e XX) (pp. 55-112). It is part of the work directed by Rita Hofstetter and Wagner Rodrigues Valente under the title "Saberes em (trans)formação - tema central da formação de professores" (2017). São Paulo: Editora Livraria da Física.

${ }^{4}$ Hofstetter et al. (2017) situated the institutionalization process of experts in education in the beginning of the $19^{\text {th }}$ century (CE) in Switzerland, when the Public Instruction Department (DIP) attributed to the Research Bureau, in 1918, the task of entering schools and gathering concrete elements in order to assess them. Such process was not limited to the far corners of Switzerland; it represents a much wider movement, as in Brazil (Morais, 2017).

5 "Expertise" is understood here as a specific competency in a given field/domain. In other words, it is to know how to do and, more than that, it is to know what to say (Veitl, 2005).
} 
According to Hofstetter et al. (2013), the selection of expertise strongly participates in the production of knowledge in the education sciences field, and it is one of the hypotheses that the researchers discuss in their studies.

The investigation produced by Hofstetter et al. $(2013)^{6}$ generated interest in the same research topic at Grupo de Pesquisa de História da Educação Matemática ${ }^{7}$ (Ghemat), but with focus on Brazil as our research environment. In this research group, we aim at investigating processes and dynamics of constitution of professional knowledge by teachers who teach mathematics ${ }^{8}$, a theme that enables different research fronts. One of them is the front focused on studying the figures, that is to say, the experts responsible for changes in teacher training knowledge - in order to avoid repetition, we stress that this study is interested in mathematical knowledge -, considering the hypothesis that they are objectification vectors of such knowledge (Morais, 2017).

What we consider "objectified knowledge" " here is in opposition to "detained knowledge" and to the statement "objectivation occurs in discursive practices that can take the form of scientific disciplines in the science system and school subjects in the school system" (Hofstetter \& Schneuwly, 2009b, p. 606). The process of objectification of knowledge is dynamic and complex. "Capturing it" from analysis and systematizing information that is dispersed in several documents means searching - in these sources - for situations of "decantation, stabilization and consensus about specific knowledge that take systematized forms to become a reference to teacher training when it comes to the constitution of teaching subjects, of scientific and school disciplines" (Valente, 2019, p. 17).

The theme experts as bringers of knowledge objectification constitutes a new investigation axis ${ }^{10}$ for Ghemat in several Brazilian states, which demands theoretical-methodological decisions that are also new ${ }^{11}$. Therefore, we started to consider some questions to reflect about "How should we analyze the production of such knowledge from a historical perspective?" and "What strategies should we adopt to consider someone an expert?". Such questions have demanded constant (re)elaboration of research methods, procedures and strategies by Ghemat group.

This is the main focus of this paper: to discuss the theoretical-methodological process for research on experts in education in order to promote a figure to the status of expert. We intend to explore the heuristic potential of the concepts here harnessed by presenting "examples" of ongoing research on the theme at Ghemat. Nevertheless, we stress that the theme should - and deserves to - be expanded in future works. This paper is organized in four sections: the first one discusses the concepts of "experts in education", "expertise" and their relation with the State; the second one conceptualizes the knowledge produced by subjects of expertise in terms of "mathematics to teach"12 and "mathematics for teaching"13; the third one, which proposes, from theoretical constructs, a theoretical-methodological path for the research on "experts in education"; and the fourth section, which illustrates ongoing research work at Ghemat guided by that theoretical-methodological path.

\title{
THE EXPERT, THE STATE AND THE SELECTION OF EXPERTISE
}

\author{
According to Hofstetter et al. (2013), the notion of expertise is understood as
}

an instance, initially acknowledged as legitimate, attributed to one or to several specialists - supposedly distinguished by their knowledge, attitudes, experiences - in order to examine a situation, to assess a phenomenon, to ascertain facts ( $p .80$, our translation).

Maxim and Arnold (2012) took into consideration the broad sense given to the notion of expertise and stressed that, unlike some research that develops new scientific and technological knowledge, expertise analyzes knowledge already existing in order to answer a question of practical order, which characterizes a difference of purpose between the academic scientific logic and expertise logic. In case existing knowledge is not enough to meet practical demand, expertise can conduct new research. Maxim and Arnold (2012) try to explicit such difference of purpose by stressing that experts are sometimes confronted with logics that are

\footnotetext{
${ }^{6}$ Rita Hofstetter is co-responsible for ERHISE (Social History of Education Research Team, in free translation) at University of Geneva, Switzerland. Retrieved on 13 feb. 2020 from: https://www.unige.ch/fapse/erhise/fr/accueil/.

${ }^{7}$ Research Group on the History of Mathematics Education, in free translation.

${ }^{8}$ Thematic Project "Mathematics in teacher training and in teaching: processes and dynamics of production of professional knowledge, 18901990", funded by FAPESP (Fundação de Amparo à Pesquisa do Estado de São Paulo - São Paulo State Research Support Foundation, in free translation) and coordinated by Wagner Rodrigues Valente. Period: 2017-2022.

9 "Objectified knowledge" belongs to "the same semantic zone as, for example, culture, rules, values [...]; it probably refers to realities in which the statute of representations, or systems of representations, made way for proactive statements and which are the object of social valuing sanctioned by a transmission-communication activity. For this reason, they have an existence that is distinct from those who state them or from those who appropriate them. They are conservable, cumulable, appropriable" (BARBIER, 2009, p. 9, our translation).

${ }^{10}$ This research front has been developed in two collective projects: the Thematic Project previously mentioned and Project No. 28/2018, Chamada Universal CNPq (CNPq Universal Call, in free translation), Faixa-C (C-Range, in free translation), "Experts and the systematization of mathematics for the first school grades, 1890-1990", coordinated by Wagner Rodrigues Valente. Period: 2018-2020.

${ }^{11}$ In Brazil, we do not identify research works that have dedicated to analyzing the trajectory of such characters, the experts, when it comes to their relevance in the production of knowledge for training and teaching. Ghemat protagonist in that research front has led researchers that are not part of our group to wonder why the term expert has been chosen rather than intellectual. It is not the aim of this text to explain similarities and/or differences between the research on experts and the one that focuses of the history of intellectuals or intellectual history. Other works have already discussed such theme. We recommend reading the article "Intellectual? No, expert!" by Morais (2019). Retrieved on 14 feb. from https://repositorio.ufsc.br/bitstream/handle/123456789/201967/Intelectual\%20No\%20-\%20Expert.pdf?sequence=1\&isAllowed=y

${ }_{12}^{12}$ Savoir à enseigner (Hofstetter; Schneuwly, 2013).

${ }^{13}$ Savoir pour enseigner (Hofstetter; Schneuwly, 2013).
} 
different from - and sometimes contradictory to - the logics that they know in the scientific community. They must interact with players whose objectives are not the same as theirs in the utilization of scientific knowledge. Maxim and Arnold also highlighted that it is not a matter of "studying, finalizing and publishing", but of making a decision that will possibly affect the lives of many people.

In the field of education sciences, Hofstetter et al. (2013) stress that there are two basic requirements for the constitution of an expert. The first one is the existing knowledge as mentioned by Maxim and Arnold - related to their professional practice, to scientific knowledge and to knowledge from experience; and the second one refers to the fact that the expert must occupy a position, a post, a chair, etc. It is from this place that an expert is invited by the State and from where he or she will try to meet practical demands. If not through his or her own knowledge, demand will be met through knowledge shared by others experts, who will be invited by him or her. Such expertise - individual or collective - provides data of several natures, which varies according to the field they are part of. In education sciences, that production and objectification refer to new specific knowledge for school functioning, like the elaboration of teaching programs, courses for teachers and other activities related to their expertise (Almeida; Valente, 2019). This expertise has the "function of systematizing knowledge in search of knowledge that is more and more coded, likely to enjoy circulation and to be used in schools, which leads to objectified knowledge" (Idem, p.325, our translation).

About the selection and invitation of the expert, Maxim and Arnold (2012, p.10, our translation) highlight that "first of all, it must be based on his or her competency to produce knowledge or to make decision making easier". However, in addition to the level of competence, such choice "to some extent, is conditioned to the nature of the knowledge produced and to its influence on decision-making processes". Those who summon ${ }^{14}$ it are "fully aware of the fact that choosing an expert is one of the keys to enable more or less control over the process of expertise" (Maxim; Arnold, 2012, p.10). They acknowledge him or her as an expert and summon him or her from the confluency of political interests between them. In other words, the summoning of expertise is not free from disputes and/or power games, from political relationships that involve the field, as stressed by Souza (2005, p.300, our translation): "with changes in governmental administrations, the institutional executives in the first step are also changed. There are also changes in the staff and, consequently, there is an institutional redistribution of exercise of power".

\section{ABOUT THE KNOWLEDGE PRODUCED BY EXPERTS IN EDUCATION - MATHEMATICS TO TEACH AND MATHEMATICS FOR TEACHING}

The theoretical constructs "mathematics to teach" and "mathematics for teaching" give a plural sense to "mathematics". Those categories started to be considered by Ghemat-Brazil based on research by Hofstetter and Schneuwly (2009a), where they stated that

Training, like any other human activity, involves deploying knowledge for its establishment, to perform the task, the specific work. This knowledge constitutes working tools15, in this case, knowledge for training or knowledge for teaching [...]. It is mainly knowledge about "the object" 16 of the teaching and training work (about knowledge to teach and about the student, the adult person, his or her knowledge, development, ways of learning, etc.), about teaching practices (methodology, procedures, devices, selection of knowledge to teach, modes of organization and management) and about the institution that defines the professional field of activity (study plans, instructions, purposes, administrative and political structures, etc.) (Hofstetter \& Schneuwly, 2009a, p.19, our translation, italics by the authors).

Inspired by Foucault (1969), Hofstetter and Schneuwly (2009b) define "knowledge" [savoir] as "the series of systematically produced statements or procedures incorporated in circumscribed, discursive, socially constituted and accepted practices. In other words, we refer here to what some call 'objective knowledge', as opposed to 'detained knowledge'" (Hofstetter \& Schneuwly, 2009b, p.606).

From these theoretical references, the categories "mathematics to teach" (the object of teacher's work ${ }^{17}$ ) and "mathematics for teaching" (the kind of knowledge specific for mathematics teachers ${ }^{18}$, that characterizes their profession), constitute theoretical categories of research and should be analyzed in an articulated way.

Before we discuss those theoretical constructs, it is important to reflect on some of the different understandings about mathematics. There are those who defend a singular form of mathematics and others who admit the existence of mathematics in the plural. The former stress that mathematics holds different levels of sophistication, which makes it a singular, whereas the latter understand that there are different kinds of mathematics, as defended by Ziegler and Loos (2015) in the following paragraphs.

\footnotetext{
${ }^{14}$ The summoning of an expert in the field of "education sciences" stems from the State. It must be located in its historical time, that is, in the beginning of the $20^{\text {th }}$ century in Brazil, for example, school principals were appointed by the State. They were "the experts, the bearers of the science of conducting classes in courses due to their experience and supposedly better training in teaching" (Valente, 2017, p.215). As the school system is developed, such expertise is institutionalized, and new figures take their places according to specific invitations for particular practical demands.
}

15 "des outils de travail" (Hofstetter; Schneuwly, 2009a)

16 "[...] de savoirs sur "l'objet" du travail d'enseignement et de formation [...] (Idem, p.19)

17 "les objets de leur travail" (Idem, p.18)

18 "les savoir qui sont les outils de leurs travail” (Idem, p.18). 
In the paper "What is Mathematics? and why we should ask, where one should experience and learn that, and how to teach it", Ziegler and Loos (2015) highlight that all impressions and experiences acquired by a teacher when he or she was a student in college will be obsolete at a future time. Although a teacher has been working for decades, mathematics changes! Everything that has been proved in mathematics is considered true; however, of course, it is known that rigor patterns do not change like they used to change in the $19^{\text {th }}$ century, for instance. Nevertheless, Ziegler and Loos stress that evaluation styles change. For example, we could analyze tests taken through a computer and how such tests are verified by the same method. Supposing a teacher could name his or her work as "current research topics", it would also be changed within ten or twenty years (Ziegler; Loos, 2015).

Ziegler and Loos (2015) say that discussions about the classification of mathematics show the difficulty in "cutting" a science into "pieces", and it is even arguable if there is any sense in separating applied research from pure mathematics, for instance ["school mathematics", a third category, could also be included here]. They say that the most diplomatic way would probably be to recognize that there are "many types of mathematics". In other words, many answers could be used for the question "What is mathematics?" and they would reveal a lot about who answers it, as far as this person is able to characterize the subject.

Following the same path, Santos and Lins (2016) advocate - bases on different studies - that there are differences between "academic mathematics" and "school mathematics", that is, between the knowledge of the subject field and the knowledge that primary school teachers harness in their professional practice. They highlight that while academic mathematics involves, for instance, the axiomatic-deductive discourse, school mathematics - the one that will be taught by a primary school teacher within multiple constraints imposed by school institutions, classrooms and the educational practice of teachers - represents "an amalgam of knowledge managed by a specific logic of educational work, even though it involves a multiplicity of constraints" (Santos; Lins, 2016, p. 358, our translation).

This article assumes the existence of "several mathematics" and it also supports Ziegler and Loos's (2015) ideas that "mathematics changes".

Having assumed that "mathematics changes", "mathematics to teach" and "mathematics for teaching" are not apart from that notion, that is to say, they are not something given, but cultural products that deserve to be historicized, because the act of recognizing historical figures is essential for the establishment of "bonds between the subjective plane of senses and the objective plane of social practices" (Vieira, 2008, p.80, our translation). One of the perspectives of analysis of such changes aims at identifying the figures responsible for guiding knowledge about teacher training and teaching over time, that is, the experts in education. So, in order to illustrate what this paper discusses - while we highlight that the theme cannot be totally explored here -, we discuss the methodological treatment for this kind of research so as to identify a subject as an expert from the knowledge that he or she produced. It should be emphasized that knowledge is the focus of research, with the expert being a vector of their production.

\section{THEORETICAL-METHODOLOGICAL TRAJECTORY OF THE RESEARCH ON EXPERTS}

Assuming that "knowledge" is a cultural product that undergoes transformations over time, the historiography of such knowledge is constituted as a synthesis of opposites, a chronology resource that acknowledges that

the place of production authorizes the text before any other sign [...]. The opposite "of the meaning" through which the present tries to understand the past. This meaning is interwoven with its opposite (Certeau, 2013, pp. 95 e 98, our translation).

For Certeau, the writing of history is unfolded, layered, fragmented:

Historiographical speech is the one that "understands" its other - chronicles, files, documents -, that is to say, that which is organized in layers, of which one half - continuous - sustains the other half - disseminated -, thus enabling the power of saying what the other means without knowing it. Through "quotes", references and notes and through all the lack of understanding that is permanent to an original language [...] it is established as knowledge of the other (Certeau, 2013, p. 100 , italics by the author).

Assuming history as unfolded writing, it then has the triple task of summoning the past, which is not in the present speech; of showing the competence of the historian, who owns the sources; and of convincing readers:

according to this aspect, the unfolded structure of speech works like a machinery that extracts from a quote the likelihood of the report and the validity of knowledge. It produces credibility (Certeau, 2013, p. 101, our translation).

Chartier (2009) summarizes Certeau's words: "history is a speech that defines, in this term, 'the possibility of establishing a set of rules that allow 'controlling' operations proportional to the production of specific objects'“ (Chartier, 2009, p.16, our translation). And draws attention to all words contained in this quote saying that

"the production of specific objects" points to the construction of the historical object by the historian, because the past is never an object that is already there; "operations" means the specific practices of a historian's work (cutting and processing sources, harnessing specific analysis techniques, construction of a hypothesis, verification procedures); "rules" and "controlling" inscribe the history of a regime of shared knowledge, defined by evidence criteria endowed with universal validity (Chartier, 2009, p. 16 , our translation). 
This article aims at providing elements of the "operations" that have been performed in research works that are interested in the process of historical and social construction of the teaching profession, with emphasis on the knowledge produced, systematized and objectified by education experts. They are subject to the "rules" and "controlling" mentioned by Chartier (2009) in the scope of Cultural History. In this study, the "production of specific objects" aims at bringing visibility to characters, experts that took active part in the processes and dynamics of objectification of mathematical knowledge for teacher training (Valente et al., 2017). Such historical objects constitute elements in the process of social and historical construction of the teaching profession - of professionalization -, which are characterized in this text through the relations established over time between mathematics to teach and mathematics for teaching.

This is the theoretical-methodological perspective of Cultural History adopted in this text for the historiographical writing, the same used in the Project "Mathematics in teacher training and in teaching: processes and dynamics of production of professional knowledge, 1890-1990", previously mentioned. Categorized as a "Thematic Project", it encompasses research organized in four axes $^{19}$ that have the objective of building different historical objects to meet its general goal: "To investigate the processes and dynamics of the constitution of professional knowledge in teachers who teach mathematics in the period between 1890-1990" (Valente et al., 2017, p.30)

Guidance by Cultural History theoretical-methodological approach is added to guidance suggested by Valente (2018). Based on What is the History of Knowledge by Peter Burke (2015), Valente stresses that the characterization of processes that bring individual's experience to knowledge acknowledged as scientific involves investigation steps that follow specific procedures: "recompilation of teaching experience ${ }^{20}$; comparative analysis of teaching knowledge; systematization and use of the data as knowledge 21". $^{21}$

The theoretical-methodological systematization introduced by Valente (2018) for research on teacher's professional knowledge opened space for this proposal. Even though it can guide the four pillars of the Thematic Project, when we take a closer look at it, we face the need for clarifying the theoretical-methodological path of the research on experts beyond Cultural History references.

It is perceptible that both ongoing collective projects at Ghemat, presented in this text, have a single bigger objective: analyzing the processes and dynamics in the constitution of professional knowledge of the teacher who teach mathematics. Our close observation revealed that, although there is a bigger goal, the intricacies of ongoing investigations may take on different methodological forms. One example is the Project under the title "Experts and the systematization of mathematics in the first school grades, 1890-1990". In it, the methodological strategy consists of: $i$ ) always starting from a figure that has had an active participation in teacher training or in teaching, assuming, as a research hypothesis, that he or she is an expert; ii) reconstructing his or her trajectory, relating it to the contexts in which he or she circulated; iii) highlighting his or her participation in the elaboration of new knowledge of mathematics to and for teaching ${ }^{22}$. Such evidence is possible through a comparison between the knowledge produced and the knowledge that was previously in circulation about the object of study ${ }^{23}$. If the third step is confirmed, the next will be to iv) acknowledge such figure as an expert, thus confirming the research hypothesis. The studies in this project are connected to the "collection of biographical data, of developed works, of documents and positions occupied by the players that significantly contributed to the transformations of mathematics in the first years of school and of teacher training" (Valente et al., 2017, p. 34, our translation).

Whereas this project focuses on a figure - a hypothetical expert -, in the other project, under the title "Mathematics in teacher training and in teaching: processes and dynamics of production of professional knowledge, 1890-1990", such figure can be both a $\mathrm{start}^{24}$ or a goal. The next paragraph will discuss the latter, because the former follows the same strategy as the one mentioned in the previous paragraph.

\footnotetext{
${ }^{19}$ The first one focuses on studying experts in education; the second one analyzes elaboration processes of mathematics to teach; the third one analyzes such processes with regard to mathematics for teaching; the fourth one considers the processes and dynamics of the mathematics that is taught. The invariable aspect among them is the professional knowledge of educators who teach mathematics. However, in research processes, the circularity among them is acceptable.

${ }^{20}$ Valdemarim and Campos (2007) stress that the activities compiled in pedagogic manuals, for example, are records and syntheses of practices that were well-succeeded and approved of by teaching experience. They say that the authors of this kind of document are based on their own teaching experience. Once they occupy positions in school hierarchic bureaucracy and are connoisseurs of pedagogical literature, they are "able to discriminate the aspects that can be transformed into guidance to practice, in addition to knowing education legislation and looking for alternatives in order to introduce innovations. When they are configured as didactic manuals, prescriptions start to be part of a rationalized speech that must be a pedagogic practice and, therefore, a documented record of the pedagogical thinking of a time, which has the main objective of becoming a teaching action" (Valdemarim, Campos, 2007, p. 344, our translation).

${ }^{21}$ Valente (2018) differentiates "knowing" from "knowledge". According to him, in methodological terms, "the former is more linked to subjectivity, to experiences lived by subjects, the implicit means of action, of reasoning; the latter is the result of a systematization of a more consensual nature, prone to generalization and objectification, a historically institutionalized cultural product whose result is the systematization and organization of specific knowledge in order to propitiate its communication" (Valente, 2018, p. 381, our translation)

${ }^{22}$ Assuming that the production of new knowledge is not confirmed, the research will be able to characterize the knowledge objectified in training and in teaching at that historical moment (Maciel, 2019; Oliveira, 2017; Pinheiro, 2017). That is, research conducted in order to identify the production of new knowledge interests research on experts. The non-verification of new knowledge leads researchers to refuting such hypothesis, but it enables them to elaborate a historical object in terms of mathematics to and for teaching.

${ }^{23}$ This step of the process can follow, in terms of methodology, the systematization as described by Valente (2018).

${ }^{24}$ See "Os experts e a produção de saberes para a docência: primeiros estudos do acervo Lydia Lamparelli" (Almeida, Valente (2019), Doi: 10.26512/lc.v25i0.23109. UNB Journals.
} 
The first step takes into consideration what was described by Valente (2018) about a "recompilation of teaching experiences", which happens through the selection and separation of information contained in documents, resulting in a collection of knowledge spread through a historical period. In other words, it is $i$ ) to analyze a whole group of documents $\mathrm{s}^{25}$ in order to form a collection that will be analyzed in search of proposition tendencies and construction of pedagogical consensus about teachers' work. The next step consists of ii) systematizing the use of knowledge through an analysis guided by theoretical references that have knowledge as a main theme. The product of this operation is "objectification". In other words, analysis and systematization are "processes", the theoretical exercise of a researcher. Once the systematization is done, in the next step the research shows that the knowledge that has been objectified in terms of mathematics to teach and for teaching. The following questions may help the researcher to conduct this step: What is the nature of this knowledge in terms of teacher's objects of work and tools, that is, in terms of mathematics to and for teaching? Does the analysis allow the researcher to state that they constitute new training knowledge? If so, the researcher will be able to acknowledge the knowledge producer as an expert.

With all this in mind, the historical object of research, according to such standpoint, leads to the characterization of new knowledge developed in terms of mathematics to and for teaching and, at the same time, acknowledges the historical agents of production of new knowledge, that is, the experts. Such acknowledgement, according to Vieira's previously mentioned view, is essential to the establishment of the "bonds between the subjective plane of senses and the objective plane of social practices".

\section{ILLUSTRATING THE THEORETICAL-METHODOLOGICAL PROCEDURES IN RESEARCH ABOUT EXPERTS IN EDUCATION}

The investigation "Uma caracterização do cálculo mental objetivado por Maria do Carmo Santos Domite para a formação de professores, $1980-1996^{26}$ " $27^{7}$ is an example of the theoretical-methodological procedure that takes a figure as a starting point - the first of the procedures previously mentioned.

Maria do Carmo Santos Domite is the researcher whose production work ${ }^{28}$ is being analyzed by Antônio R. C. Conceição based on the hypothesis that aims at investigating the participation of Domite in processes and dynamics of production and objectification of knowledge about mental calculation for teacher training.

Among the analyzed documents are articles by Domite that discuss mental calculation (Domite, 1989, 1995, 1996) and training courses for teachers and managers. The analysis of the documents led Conceição to build the researcher's professional trajectory, relating her to the context of those productions. It enabled him to find other documents, like her career memorial, her habilitation thesis, and others, which contain testimonials by Domite where she states that she had attended teacher training courses in the 1980 s at "Secretaria Municipal de Educação de São Paulo"29 at "Fundação Brasileira para o Desenvolvimento do Ensino de Ciências" - FUNBEC ${ }^{30}$, "Departamento de Orientação Técnica - DOT" 31 . In addition, she was the author of propositions, a critical reader and coordinator of teacher training courses.

About her participation at FUNBEC, Domite was invited to be part of the team that developed - in a partnership with INEP (Instituto Nacional de Estudos e Pesquisas Educacionais ${ }^{32}$ - the "Curso de Matemática por Correspondência - Programa de Educação Continuada para professores leigos"33. Her invitation to work for DOT was published in the Official Gazette in 1985:

I authorize [...] the hiring of Mrs. Maria do Carmo Domite Mendonça ${ }^{34}$ to perform specialized technical work as described here (training for pedagogical coordinators and supervisors in early childhood education municipal schools) [....] (Brazil, 1985, p. 10-11 apud Conceição, work in progress).

At the moment, the research is in the stage of analysis and systematization of the inventoried knowledge as objectified knowledge by Domite. The systematization of knowledge that is spread through a given historical time is a theoretical exercise for the researcher whereas objectification is performed by the authors of the documents/works analyzed. In the case of Conceição's research, the knowledge was objectified by Domite. Valente (2018) describes this process as "an asepsis of subjective and conjunctural elements of pedagogical consensus so that knowledge can be susceptible to generalization and use, that is, as knowledge to be used" (p.381). A bibliographic search about the topic of the investigation, mental calculation, is also part of this stage in order to perform a comparative analysis between the objectified knowledge and knowledge in circulation, an exercise necessary to characterize a knowledge as new and, at the same time, in terms of mathematics to teach or for teaching. This comparative analysis also enables the researcher to recognize his historical production agents as experts.

\footnotetext{
${ }^{25}$ To adopt such methodological strategy, researchers should consider documents of different natures, like pedagogical manuals, textbooks, school notebooks, articles, regulations, pedagogic journals, courses for teachers, etc.

${ }^{26}$ Under a provisional title, this investigation is being developed by Antônio Robert Chagas Conceição and guided by Rosilda dos Santos Morais in the master level.

${ }^{27} \mathrm{~A}$ Characterization of mental calculation as aimed by Maria do Carmo Santos Domite for teacher training, 1980-1996, in free translation.

${ }^{28}$ The documents that are being analyzed are part of Domite's personal collection and are being inventoried for future public online access by GHEMAT-Brazil.

${ }^{29}$ São Paulo City Education Department, in free translation.

${ }^{30}$ Brazilian Foundation for the Development of Science Teaching, in free translation.

${ }^{31}$ Technical Guidance Department, in free translation.

${ }^{32}$ National Institute of Education Research and Studies, in free translation.

${ }^{33}$ Mathematics Correspondence Course - Continuing Education Program for Leigh Teachers, in free translation.

${ }^{34}$ Mendonça was Maria do Carmo's married name. She used the name Maria do Carmo Domite Mendonça before.
} 
Conceição's research stages follow the proper practices of the historian's task through a selection and processing of sources, mobilization of specific analysis techniques, construction of a hypothesis, procedures of verification (Chartier, 2009).

Another research work that illustrates the second theoretical-methodological procedure that we presented is the investigation that has been done by Jefferson S. Ferreira ${ }^{35}$ under the provisional title "A aritmética na Escola Normal de São Paulo: processos e

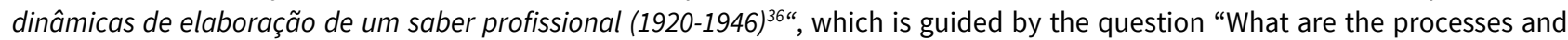
dynamics of elaboration of professional knowledge of the teacher in training at Escola Normal de São Paulo ${ }^{37}$ for the teaching 'arithmetic made to measure' ${ }^{38}$ ?". Ferreira's research hypothesis suspects that if scientific pedagogy transformed school arithmetic into "arithmetic made to measure" 39 (Pinheiro, 2017), transformations in teacher training knowledge were somehow necessary. In other words, the elaboration process of a new school arithmetic changes the dynamics of professional knowledge of teachers who teach (or who will teach) such knowledge, thus modifying the articulations between mathematics to teach and for teaching and generating new professional knowledge.

Based on Ferreira's research question and hypothesis, the focus of his investigation is in the transformations of arithmetic as reference knowledge at Escola Normal de São Paulo from 1920 to 1946. However, after accessing documents from the institution through visits to "Núcleo de Memórias e Acervo Histórico do Centro de Referência em Educação" Mário Covas (NUMAH/CRE) ${ }^{40}$ and to "Acervo Paulo Bourrol da biblioteca da Faculdade de Educação da Universidade de São Paulo" ${ }^{41}$ (FEUSP), a figure is gaining prominence due to his numerous productions for the training of teachers who taught mathematics in the first decades of the 20th century: José Ribeiro Escobar, a mathematics teacher at Escola Normal de São Paulo in the 1920s. Ferreira also identified official publications informing of Escobar's leave from São Paulo state to help renew public instruction in Pernambuco state, a fact that might be connected to an acknowledgement of his expertise by the community.

Ferreira's research might confirm or reject his hypothesis presenting, as its historical object, the processes and dynamics of elaboration of professional knowledge for the teaching of "arithmetic made to measure" at Escola Normal de São Paulo. Nevertheless, another research path could be to consider his "research findings", which might lead to the identification of José Ribeiro Escobar as a historical agent in the production of training knowledge in that historical period, that is, as an expert ${ }^{42}$. It is important to highlight that a third possible path could be to join the two possibilities previously mentioned. However, we understand and respect the limitations imposed to the research. Regardless of the option that will be followed, as stated by Certeau (2013), the text ends, but the research goes on...

\section{CONCLUSION}

In this article, we assume that teaching knowledge is a cultural product that undergoes transformations and is dynamized by demands from this culture. The research that investigates such processes and dynamics requires a specific theoreticalmethodological approach, and we believe that the elements provided here contribute to the debate on the processes of elaboration and objectification of knowledge by education experts in training and in teaching. The analysis and systematization of objectified knowledge in these two fields is the researcher's intellectual activity supported by the theoretical-methodological references harnessed here, whose historical products is mathematics to teach and for teaching - respectively, teacher's object of work and working tools - and the acknowledgment of their historical production agents, the experts in education.

\section{REFERENCES}

Almeida, A. F., \& Valente, W. R. (2018). Os experts e a produção de saberes para a docência: primeiros estudos do acervo de Lydia Lamparelli (pp. 318-332). https://doi.org/10.26512/lc.v25i0.23109

Barbier, J. M. (2009). Savoirs Théoriques et Savoirs d'Action. [Introduction]. Paris: Presses Universitaires de France, 1996.

Burke, P. (2015). O que é História do Conhecimento? São Paulo: Editora Unesp.

Certeau, M. (2013). A Escrita da História. Rio de Janeiro: Forense.

Chartier, R. (2009). A história ou a leitura do tempo. Belo Horizonte: Autêntica Editora.

Dumoulin, L., La Branche, S., Robert, C., \& Warin, P. (2005). Un passage obligé, une figure impose. In L. Dumoulin, S. La Branche, C. Robert, \& P. Warin (eds), Le Recours aux experts - raisons et usages politiques (pp. 9-14). Grenoble, France: Presses Universitaires de Grenoble.

Hofstetter, R., \& Schneuwly, B. (2009a). Introduction. Savoir en(trans)formation. Au coeur des professions de l'enseignement et de la formation" (pp.7-40). In R. Hofstetter et al., Savoirs en (trans)formation, De Boeck Supérieur "Raisons éducatives". https://doi.org/10.3917/dbu.hofst.2009.01.0007

\footnotetext{
${ }^{35}$ Jefferson dos Santos Ferreira is doing doctoral research work under the guidance of Wagner Rodrigues Valente.

${ }^{36}$ Arithmetic in São Paulo Normal School: processes and dynamics of professional knowledge elaboration (1920-1946), in free translation.

${ }^{37}$ São Paulo Normal School, in free translation.

${ }^{38}$ Ferreira bases the concept of "arithmetic made to measure" on Pinheiro (2017).

39 "Arithmetic made to measure" was inspired by Edouard Claparède's “l'école sur mesure" (1901) (Pinheiro, 2017).

${ }^{40}$ Historical Collection and Memorial of Mário Covas Education Reference Center, in free translation.

${ }^{41}$ Paulo Bourrol Collection at São Paulo University Education College Library (FEUSP), in free translation.

${ }^{42}$ If Ferreira chooses to follow this path, the methodological procedure will be the one that focuses on the expert as the goal.
} 
Hofstetter, R., \& Schneuwly, B. (2009b). Knowledge for teaching and knowledge to teach: two contrasting figures of New Education: Claparède and Vygotsky. https://doi.org/10.1080/00309230903100973

Hofstetter, R., \& Schneuwly, B. (2017). Saberes: um tema central para as profissões do ensino e da formação. In R. Hofstetter, \& W. R. Valente. Saberes em (trans)formação - tema central da formação de professors (pp.113-172). São Paulo: Editora Livraria da Física.

Hofstetter, R., Schneuwly, B., Freymond, M., \& Bos, F. (2013). "Pénétrer dans la vérité de l'école pour la juger pièces en main" L'irrésistible institutionnalisation de l'expertise dans le champ pédagogique (XIXe - Xxe siècles). In P. Borgeaud, K. Bruland, J. Lacki, M. Porret, M. Ratcliff, \& B. Schneuwly (eds). La Fabrique des savoirs. Figures et pratiques d'experts (pp. 80-116). Genève: Les Éditions Médecine et Hygiène - Georg.

Maciel, V. B. (2019). Elementos do saber profissional do professor que ensina matemática: uma aritmética para ensinar nos manuais pedagógicos (1880-1920) (Doctoral Thesis), São Paulo.

Maxim, L., \& Arnold, G. (2012/3). Entre Recherche Académique et Expertise Scientifique: des Mondes de Chercheurs. C.N.R.S Edition. Hermès, La Revue. https://doi.org/10.4267/2042/48375

Morais, R. S. (2017). Experts em educação e a produção de saberes no campo pedagógico (pp. 61-70). https://doi.org/10.37084/REMATEC.1980-3141.2017.n26.p\%25p.id110

Oliveira, M. A. (2017). A aritmética escolar e o método intuitivo: um novo saber para o curso primário (1870-1920) (Doctoral Thesis), São Paulo.

Pinheiro, N. V. (2017). A aritmética sob medida: a matemática em tempos da pedagogia científica (Doctoral Thesis), São Paulo.

Santos, J. V., \& Lins, R. C. (2016) Uma discussão a respeito da(s) matemática(s) na formação inicial de professores de matemática (pp. 351-371). Retrieved on 1 May 2020 from https://revistas.pucsp.br/emp/article/view/20429

Shanteau, J. (1992). Competence in Experts: The Role of Task Characteristics. Organizational Behavior and human decision processes (pp. 252-266). https://doi.org/10.1016/0749-5978(92)90064-E

Souza, Z. D. (2005). Educação Matemática na CENP: um estudo sobre condições institucionais de produção cultural por parte de uma comunidade de prática (Doctoral Thesis), Faculdade de Educação. Campinas. Retrieved on 1 May 2020 from http://www2.fc.unesp.br/ghoem/trabalhos/34_7_Tese_Gilda.pdf

Valdemarim, V. T., \& Campos, D. G. S. (2007). Concepções pedagógicas e método de ensino: O manual didático Processologia na Escola Primária (pp. 343-356). https://doi.org/10.1590/S0103-863X2007000300005

Valente, W. R. (2017) A matemática a ensinar e a matemática para ensinar: os saberes para a formação do educador matemático, In R. Hofstetter \& W. R. Valente (orgs.), Saberes em (trans)formação - tema central da formação de professores (pp. 201-228). São Paulo: Editora Livraria da Física.

Valente, W. R. (2018). Processos de Investigação Histórica da Constituição do Saber Profissional do Professor que Ensina Matemática (pp. 377-385). https://doi.org/10.17648/acta.scientiae.v20iss3id3906

Valente, W. R. (2019). Saber objetivado e formação de professores: reflexões pedagógico-epistemológicas (pp. 1-22). https://doi.org/10.1590/2236-3459/77747

Valente, W. R., Bertini, L. F., Pinto, N. B., \& Morais, R. S. (2017). A matemática na formação de professores e no ensino - processos e dinâmicas de produção de um saber profissional, 1890-1990 (Thematic Project). FAPESP, Processo n. 17/15751-2

Veitl, P. (2005). À quoi pensent les experts? Paroles d'experts et paroles sur l'expertise. In L. Dumoulin et al. Le recours aux experts - Raisons et usages politiques (pp. 15-36). Presses Universitaires de Grenoble.

Vieira, C. E. (2008). Intelligentsia e intelectuais: sentidos, conceitos e possibilidades para a história intelectual. Retrieved on 1 May 2020 from http://periodicos.uem.br/ojs/index.php/rbhe/article/view/38588

Ziegler, G. M., \& Loos, A. (2017). "What is Mathematics?" and "Why we should ask, where one should experience and learn that, and how to teach it”. https://doi.org/10.1007/978-3-319-62597-3_5 